$\underline{\text { Research Article }}$

\title{
Effect of Javanese Turmeric (Curcuma xanthorrhiza) Extract on Hepatitis Model of Alcohol-Induced Mice
}

\section{Pengaruh Ekstrak Rimpang Temulawak (Curcuma xanthorrhiza) terhadap Gambaran Model Hepatitis Mencit yang Diinduksi Alkohol}

\author{
Agnes llene $S P^{1}$, Willy Sandhika ${ }^{2}$, Nurina Hasanatuludhhiyah ${ }^{3}$ \\ ${ }^{1}$ Medical Study Program Faculty of Medicine Universitas Airlangga Surabaya \\ ${ }^{2}$ Department of Anatomical Pathology Faculty of Medicine Universitas Airlangga Surabaya \\ ${ }^{3}$ Department of Pharmacology Faculty of Medicine Universitas Airlangga Surabaya
}

\begin{abstract}
Alcoholic hepatitis is a common cause of non-viral hepatitis. Javanese turmeric (Curcuma xanthorrhiza) contains xanthorrhizol and curcuminoid that have antioxidant and anti-inflammatory effects. The purpose of this research was to detect the effect of Curcuma xanthorrhiza in decreasing hydropic degeneration and lymphocytes in alcohol-induced mice. This experimental research used post-test only controlled design. Randomly, 35 mice were divided into five groups. Four groups were induced by alcohol $30 \%$ of $4 \mathrm{ml} / \mathrm{kgBW}$ in 10 days, and one group was normal group (negative control). Three of the four alcohol-induced groups were given Curcuma xanthorrhiza extract at doses of 42, 84, and $168 \mathrm{mg} / \mathrm{kgBW}$ in $10 \mathrm{days,}$ 1 hour after alcohol induction. Mice livers were taken for Hematoxylin Eosin (HE) staining. Hydropic degeneration and lymphocytes in the liver lobules were examined under a microscope. The statistical analysis used in this research was the Kruskal-Wallis, the Mann-Whitney test, and the Independent Sample T Test. P-value is significant if $<0.05$. The result of this research were all doses of Javanese turmeric extract significantly reduced hydropic degeneration. Doses of 84 and 168 $\mathrm{mg} / \mathrm{kgBW}$ also reduced inflammatory lymphocytes $(p<0.05)$. The dose of $168 \mathrm{mg} / \mathrm{kgBW}$ reduced the lymphocyte inflammation maximally. There was no significant difference between increasing Javanese turmeric dose and decreasing hydropic degeneration and lymphocytes ( $p>0.05)$. This research shows that Javanese turmeric (Curcuma xanthorrhiza) can attenuate hepatitis by decreasing hydropic degeneration and lymphocytes in alcohol-induced liver.
\end{abstract}

Keywords: Alcohol, curcuma xanthorrhiza, hepatitis, hydropic degeneration, lymphocyte inflammation cell

\begin{abstract}
ABSTRAK
Hepatitis alkoholik merupakan hepatitis non virus yang sering dijumpai. Rimpang temulawak (Curcuma xanthorrhiza) memiliki kandungan xanthorrhizol dan kurkuminoid yang memiliki efek antioksidan dan antiinflamasi. Tujuan penelitian ini adalah mengetahui efek temulawak (Curcuma xanthorrhiza) dalam mengurangi gambaran degenerasi hidropik dan limfosit pada hepar mencit yang diinduksi alkohol. Penelitian eksperimental ini menggunakan post-test only controlled design. Secara acak, 35 mencit jantan dibagi menjadi 5 kelompok. Empat kelompok diinduksi dengan alkohol 30\% sebanyak $4 \mathrm{ml} / \mathrm{kgBB}$ selama 10 hari, dan satu kelompok merupakan kelompok normal (kontrol negatif). Dari kelompok yang diinduksi alkohol tersebut, tiga kelompok diberi ekstrak etanol rimpang temulawak dosis 42, 84, dan $168 \mathrm{mg} / \mathrm{kgBB}$ selama 10 hari, satu jam setelah induksi alkohol. Sehari setelah itu, hepar mencit diambil untuk pewarnaan Hematoxylin Eosin (HE). Pengamatan yang dilakukan adalah rata-rata degenerasi hidropik dan limfosit pada lobulus hepar. Analisis statistik yang digunakan pada penelitian ini yaitu Kruskal-Wallis, Mann-Whitney test dan Uji T Independent Sample. Nilai p bermakna apabila $<0.05$. Hasil penelitian ini adalah semua dosis temulawak dapat menurunkan degenerasi hidropik secara bermakna. Dosis temulawak 84 dan $168 \mathrm{mg} / \mathrm{kgBB}$ juga dapat menurunkan inflamasi limfosit $(p<0.05)$. Pada inflamasi limfosit, dosis ekstrak $168 \mathrm{mg} / \mathrm{kgBB}$ memberi gambaran penurunan yang maksimal $(p<0.05)$. Tidak ada perbedaan bermakna antara peningkatan dosis temulawak dengan penurunan degenerasi hidropik dan limfosit ( $p>0.05)$. Penelitian ini menunjukkan bahwa temulawak (Curcuma xanthorrhiza) dapat mengurangi gambaran hepatitis akibat alkohol melalui penurunan degenerasi hidropik dan limfosit.
\end{abstract}

Kata Kunci: Alkohol, curcuma xanthorrhiza, degenerasi hidropik, hepatitis, sel limfosit

Correspondence: Agnes Ilene SP. Medical Study Program Faculty of Medicine Universitas Airlangga Surabaya, Jl. Mayjen Prof. Dr. Moestopo No.47Surabaya, Jawa Timur Tel.081946568327Email:agnes.ilene.suprapto-2016@fk.unair.ac.id 


\section{INTRODUCTION}

Hepatitis is a liver inflammation characterized by inflammatory cells and can be caused by viral and nonviral infections (1). The causes that are commonly found in non-viral hepatitis and become a global problem are hepatitis due to alcohol (Alcoholic Liver Disease) and metabolic disorders (Non-Alcoholic Fatty Liver Disease). In 2016, alcohol use was the seventh leading death and DALY (Disability-Adjusted Life Year), and caused around 2.8 million mortality (2). Research states that about $10-35 \%$ of alcoholism will become alcoholic steatohepatitis (ASH). The prevalence of NAFLD is around $25-30 \%$ of the global population due to metabolic diseases such as type II DM, obesity, and cardiovascular disorders (3). It is predicted that the development and modernity of life will increase the prevalence of metabolic diseases, so the risk of NAFLD development is also higher. Nearly $70 \%$ of people with NAFLD will develop steatohepatitis, or known as NASH (Non-Alcoholic Steatohepatitis) (3).

Alcohol often causes complications known as liver cirrhosis and cancer risk which increases mortality $(4,5)$. Until recently, treatment for liver cirrhosis has only been done by liver transplantation. Alcohol addiction also can cause bad effect in all domain (physicals, social, physiologies, and environment) (6). Therefore, hepatitis and alcohol addiction must be prevented and treated properly, so the complications can be prevented.

Currently, in Indonesia, the use of traditional medicines from plants is starting to grow as a therapy for diseases, one of them is Javanese turmeric (Curcuma xanthorrhiza). Javanese turmeric is often found and used in daily life by people in Indonesia as medicines, herbs, spices, aromatherapy, natural dyes in cosmetics, and pharmaceuticals. In Javanese turmeric, the chemical contents are curcuminoid, phenolic, triterpenoid, and xanthorrhizol (the main compounds) $(7,8)$. In previous studies, the contents have been proven to contain antioxidant and anti-inflammatory effects (9). Based on this reason, it is necessary to conduct research to determine the potential of Javanese turmeric (Curcuma xanthorrhiza) as an alternative therapy for hepatitis in alcohol-induced mice models.

This study aimed to determine the effect of ethanol extracts of Javanese turmeric (Curcuma xanthorrhiza) in reducing the hydropic degeneration and lymphocytes in the liver of alcohol-induced mice, and also to find out the correlation between increasing Javanese turmeric dose with decreasing hydropic degeneration and lymphocytes.

\section{METHOD}

\section{Animal Model}

This research was an experimental laboratory study using the posttest only control group design method. The sample used was 35 male white mice (Mus musculus) weighing \pm 20 -30 grams, aged 2-3 months, healthy, active, and did not show anatomical abnormalities. The samples were then grouped randomly using simple random sampling technique into five groups, namely one group without induction (negative control), one treatment group of alcohol induction (positive control), and three treatment groups of alcohol induction and Javanese turmeric extract with multi-doses. The experimental animals were treated at the Biochemistry Laboratory of
Experimental Animals Unit, Faculty of Medicine, Airlangga University. This study has obtained ethical clearance from the Health Research Ethics Committee, Faculty of Medicine, Airlangga University Surabaya No. 158/EC/KEPK/FKUA/2019.

\section{Javanese Turmeric Ethanol Extract Preparation}

Dry simplicia of Javanese turmeric powder was put into a macerator and added with 3.5 liters of alcohol solvent (ethanol 96\%), then soaked for 24 hours at room temperature. Macerate that has been soaked was filtered with filter paper and pump vacuum, and re-macerated. All macerate was then evaporated with evaporator at $50^{\circ} \mathrm{C}$ until thick extract was obtained. Dry simplicia powder was obtained from Materia Medica Batu, and extracts were made at the Pharmacology Laboratory of Faculty of Medicine, Airlangga University.

Induction of Alcohol and Javanese Turmeric Ethanol Extract

Hepatitis induction in this study used $4 \mathrm{ml} / \mathrm{kgBW}$ of alcohol $30 \%$ per day for ten days to the four treatment groups. Induction of Javanese turmeric (Curcuma xanthorrhiza) ethanol extract was given 1 hour after alcohol induction for ten days to three treatment groups (alcohol + extract). This research used $96 \%$ ethanol extract of Javanese turmeric (Curcuma xanthorrhiza) at doses of $42 \mathrm{mg} / \mathrm{kgBW}, 84$ $\mathrm{mg} / \mathrm{kgBW}$, and $168 \mathrm{mg} / \mathrm{kgBW}$. Administrations of alcohol and Javanese turmeric were done orally using a feeding pipe.

\section{Liver Microscopic Examination}

Microscopic examination of the liver was carried out by dissecting the liver of the treated mice. Mice's liver was dissected a day after the induction of alcohol and Javanese turmeric extract. The liver was fixed with $10 \%$ formalin, and then paraffin blocks and Hematoxylin-Eosin (HE) staining were made. The parameters examined were the average number of hydropic degeneration in zone 3 liver and lymphocytes in the liver lobules of the mice. The parameters were examined under a binocular light microscope at 400x magnification in five visual fields. In hydropic degeneration, a 10x10 box graticulae counting aid was used. Preparation and observation of the preparation were carried out at the Anatomical Pathology Laboratory, Faculty of Medicine, Airlangga University.

\section{Statistical Analysis}

Statistical analysis was performed using SPSS version 16 . The normality of data distribution was assessed using the Shapiro-Wilk, while the homogeneity of data was done using the Levene test. The Kruskal-Wallis non-parametric test (because the One-Way ANOVA test requirements were not meet) was carried out to determine the mean value among treatment groups. After that, the Mann-Whitney test for abnormally distributed samples and the Independent Sample T-test for normally distributed samples were performed. Statistical analysis was significant if the $p$-value $<0.05$.

\section{RESULTS}

Evaluation in this study on the average hydropic degeneration and lymphocytes in each group can be seen in Table 1. Histopathological image of hydropic degeneration and lymphocytes in the positive control group ( $4 \mathrm{ml} / \mathrm{kgBW}$ of alcohol $30 \%$ ) can be seen in Figure 1, 
while hydropic degeneration and lymphocytes in the alcohol + Javanese turmeric extract treatment groups can be seen in Figure 2.

Table 1. Data of hydropic degeneration and lymphocytes in each group

\begin{tabular}{|c|c|c|c|c|}
\hline \multirow[b]{2}{*}{ No. } & \multirow[b]{2}{*}{ Group } & \multirow[b]{2}{*}{$\mathbf{N}$} & \multicolumn{2}{|c|}{ Mean \pm SD } \\
\hline & & & $\begin{array}{c}\text { Hydropic } \\
\text { degeneration }\end{array}$ & Lymphocytes \\
\hline 1. & $\begin{array}{l}\text { Group without induction } \\
\text { (negative control) }\end{array}$ & 7 & $7.14 \pm 9.48$ & $13.43 \pm 2.07$ \\
\hline 2. & $\begin{array}{l}\text { Group of alcohol } 30 \% \\
4 \mathrm{ml} / \mathrm{kgBW} \text { (positive control) }\end{array}$ & 7 & $60.71 \pm 13.83^{(\mathrm{a})}$ & $24.71 \pm 6.47^{\text {(a) }}$ \\
\hline 3. & $\begin{array}{l}\text { Group of alcohol + Javanese } \\
\text { turmeric extract } 42 \mathrm{ml} / \mathrm{kgBW}\end{array}$ & 7 & $17.00 \pm 11.87^{(\mathrm{b})}$ & $19.14 \pm 1.77$ \\
\hline 4. & $\begin{array}{l}\text { Group of alcohol + Javanese } \\
\text { turmeric extract } 84 \mathrm{ml} / \mathrm{kgBW}\end{array}$ & 7 & $16.71 \pm 6.58^{(b)}$ & $17.57 \pm 3.95^{(b)}$ \\
\hline 5. & $\begin{array}{l}\text { Group of alcohol + Javanese } \\
\text { turmeric extract } 168 \mathrm{ml} / \mathrm{kgBW}\end{array}$ & 7 & $15.00 \pm 10.31^{(b)}$ & $15.00 \pm 2.31^{(b)}$ \\
\hline
\end{tabular}

\section{Note:}

(a). There were significant $(p<0.05)$ differences with the group without induction (negative control)

(b). There were significant $(p<0.05)$ differences with the alcohol $30 \%$ group (positive control)

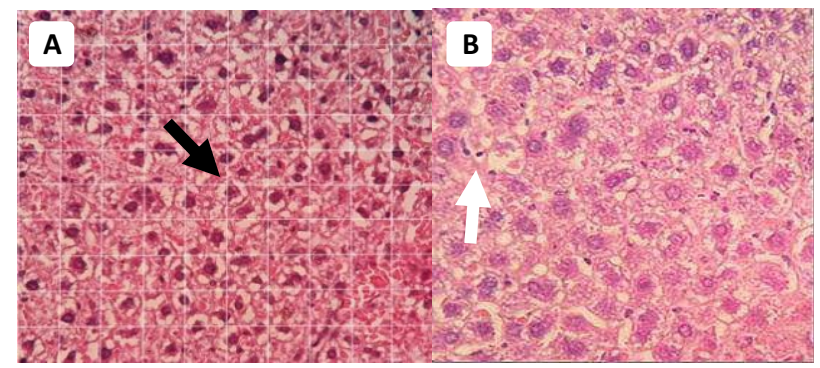

Figure 1. Image of hydropic degeneration (A) and lymphocyte infiltration (B) in $4 \mathrm{ml} / \mathrm{kgBW}$ of alcohol $30 \%$ group (positive control)

Note: Black arrow: hydropic degeneration, White arrow: lymphocytes

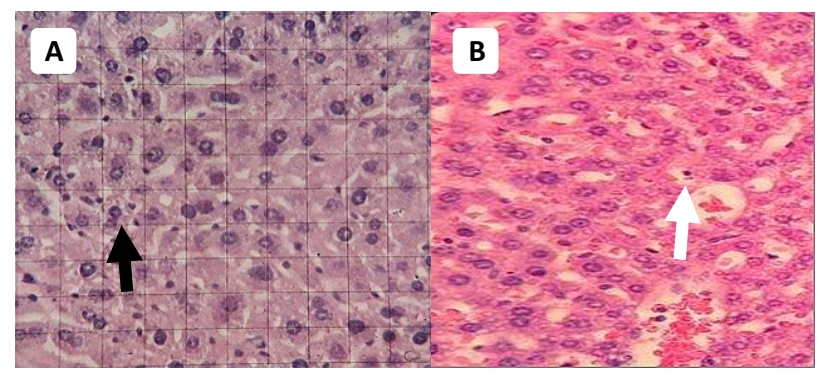

Figure 2. Image of hydropic degeneration (A) and lymphocyte infiltration (B) in the group of alcohol $+96 \%$ ethanol extract of Javanese turmeric (Curcuma xanthorrhiza) at a dose of 168 $\mathrm{mg} / \mathrm{kgBW}$

Note: Black arrow : hydropic degeneration, White arrow: lymphocytes

From the results of the Table 1 and Figure 2 above, there are differences in hydropic degeneration and lymphocyte infiltration in the five groups. The highest number of hydropic degeneration and lymphocyte infiltration were found in the positive control group (alcohol $30 \%$ only), and the least was found in the negative control group (the group without induction). The Javanese turmeric extract groups showed decreases in the number of hydropic degeneration and lymphocytes compared to the positive control group. Increased dose of Javanese turmeric extract decreased the number of hydropic degeneration and lymphocytes. The results of statistical analysis showed that in hydropic degeneration, the Javanese turmeric extract groups gave a significant decrease compared to the positive control group. Increased dose of Javanese turmeric extract in hydropic degeneration did not show a significant correlation. Whereas in lymphocyte infiltration, the doses of Javanese turmeric extract significantly reduced the number of lymphocytes compared to positive control were $64 \mathrm{mg} / \mathrm{kgBW}$ and $168 \mathrm{mg} / \mathrm{kgBW}$. Moreover, the dose of $168 \mathrm{mg} / \mathrm{kgBW}$ gave a significant decrease in the number of lymphocytes compared to $42 \mathrm{mg} / \mathrm{kgBW}$ and $64 \mathrm{mg} / \mathrm{kgBW}$.

\section{DISCUSSION}

In this study, alcohol can cause hydropic degeneration and more severe lymphocyte infiltration. Alcohol is metabolized in the liver into acetaldehyde by alcohol dehydrogenase enzyme, CYP2E1 enzyme, and catalase that produce ROS products, mitochondrial damage, and oxidative stress. Oxidative stress and ROS make ATP products decrease and disrupt the ion and fluid homeostasis in the plasma membrane, leading to increased intracellular water, which triggers hydropic degeneration (10). In addition, oxidative stress and ROS also increase chemokine and pro-inflammatory cytokines which cause inflammation, apoptotic induction, and hepatocellular damage (11). Pro-inflammatory cytokines activate other inflammatory cells and Kupffer cells. Activated Kupffer cells activate Tumor Nuclear Factor (TNF)- $\alpha$, which plays a role in the development of liver necrosis and inflammation (12). Alcohol also causes inflammation of the liver by regulating NF- B and STAT3 Tlymphocyte signaling pathways. Additionally, alcohol increases osteopontin and leptin which stimulates lymphocyte activation and proliferation (12). Another study with a dose of $12 \mathrm{ml} / \mathrm{kgBW}$ alcohol $50 \%$ for 7 days showed that alcohol induction can cause liver cell damage, namely macrovesicular steatosis, ballooning hepatocytes, and the presence of Mallory-Denk Bodies as the signs of alcoholic hepatitis (13). However, this study only investigated hydropic degeneration as an early sign of liver cell ballooning and lymphocyte infiltration.

Javanese turmeric can reduce the hydropic and lymphocyte degeneration in the liver compared to the alcohol group. Javanese turmeric (Curcuma xanthorrhiza) contains xanthorrhizol, curcumin, phenolics and triterpenoids which have anti-inflammatory and antioxidant effects that can be used as hepato-protectors and hepato-therapeutics (14). As an antioxidant, Javanese turmeric reduces ROS buildup and oxidative stress by inhibiting the enzyme CYP2E1 (9), thus maintain ATP products and ionic mechanisms in cell membranes to reach homeostasis state. Homeostatic ion decreases plasma membrane leakage and osmotic pressure, thereby reducing the hydropic degeneration (10). In addition, inhibited ROS and oxidative stress can reduce chemokine and pro-inflammatory cytokines that cause inflammation, apoptotic induction, and hepatocellular 
damage (11). As an anti-inflammatory agent, Javanese turmeric suppresses cytokines TNF- $\alpha$, IL-6, and IL-1 $\beta$, so it can suppress NF- B, MPAKs, and protein kinase B, which are prototypical pro-inflammatory signal pathways (15).

The results of this study indicate that all doses of ethanol extract of Javanese turmeric (Curcuma xanthorrhiza) can reduce hydropic degeneration in the liver of alcoholinduced mice $(p<0.05)$. While only Javanese turmeric extracts at doses of 84 and $168 \mathrm{mg} / \mathrm{kgBW}$ can reduce lymphocyte infiltration $(p<0.05)$. This is in line with previous studies using Javanese turmeric (Curcuma xanthorrhiza) ethanol extract at a dose of $500 \mathrm{mg} / \mathrm{kgBW}$ on rats that can reduce macrovesicular steatosis and inflammation, ballooning liver cells, and Mallory-Denk Bodies (13). Another study proved that Curcuma xanthorrhiza extract can reduce SGOT and SGPT levels as markers of hepatitis in the liver induced by paracetamol (16). This study also found that the decrease in hydropic degeneration did not have a significant correlation with

\section{REFERENCES}

1. Pallavi K, Sravani D, Durga S, et al. Hepatitis-A: Review on Current and Future Scenario. Journal of In Silico \& In Vitro Pharmacology. 2017; 3(1): 1-5.

2. GBD 2016 Alcohol Collaborators. Alcohol Use and Burden for 195 Countries and Territories, 1990-2016: A Systematic Analysis for the Global Burden of Disease Study 2016. Lancet. 2018; 392(10152): 1015-1032.

3. Fingas C, Best J, Sowa J, and Canbay A. Epidemiology of Nonalcoholic Steatohepatitis and Hepatocellular Carcinoma. Clinical Liver Disease. 2016; 8(5): 119-122.

4. Osna NA, Donohue TM, and Kharbanda KK. Alcoholic Liver Disease: Pathogenesis and Current Management. Alcohol Research Current Reviews. 2017; 38(2): 147-161.

5. Kunzmann AT, Coleman HG, Huang WY, and Berndt SI. The Association of Lifetime Alcohol Use with Mortality and Cancer Risk in Older Adults: A Cohort Study. PLoS Medicine. 2018; 15(6): 1-18.

6. Fonda G, Agus D, and Jani D. Alcohol Addiction Increases the Risk of Deteriorating Quality of Life, Study on: Visitors to Cafes in South Jakarta in 2018. Jurnal Kedokteran Brawijaya. 2019; 30(4): 317-322.

7. Purnomo D, Budiastuti M, Sakya A, and Cholid M. The Potential of Turmeric (Curcuma Xanthorrhiza) in Agroforestry System Based on Silk Tree (Albizia Chinensis). IOP Conference Series: Earth and Environmental Science. 2018; 142: 1-5.

8. Lew KF, Goh GL, Son R, and Rukayadi Y. Effect of Javanese Turmeric (Curcuma Xanthorrhiza Roxb.) Extract on Natural Microflora of Oyster Mushroom (Pleurotus Sajur-Caju) and Its Sensory Acceptability. International Food Research Journal. 2015; 22(6): 2446-2451.

9. Oon S, Nallappan M, Tee T, et al. Xanthorrhizol: $A$ the increase of Javanese turmeric dose ( $p>0.05)$. In decreasing lymphocyte infiltration, the most substantial dose of Javanese turmeric that was $168 \mathrm{mg} / \mathrm{kgBW}$ had a more significant effect $(p<0.05)$.

This study concluded that the ethanol extract of Javanese turmeric (Curcuma xanthorrhiza) can reduce hepatitis due to alcohol induction, namely by reducing the hydropic degeneration and lymphocyte infiltration. There is no significant correlation between increasing Javanese turmeric dose and decreasing the number of hydropic degeneration. While the extract dose of $168 \mathrm{mg} / \mathrm{kgBW}$ gives the highest reduction of lymphocyte infiltration.

\section{ACKNOWLEDGEMENT}

The researchers would like to thank the Faculty of Medicine, Airlangga University, the Department of Biochemistry of the Animal Experiment Unit, the Department of Pharmacology, and the Department of Pathology Anatomy for facilitating this research.

Review of Its Pharmacological Activities and Anticancer Properties. Cancer Cell International. 2015; 15(1): 1-15.

10. Silva FC, de Souza JGL, Reichert AM, et al. Influence of the Alcohol Present in a Phytotherapic Tincture on Male Rat Lipid Profiles and Renal Function. EvidenceBased Complementary and Alternative Medicine. 2015; 2015: 1-11.

11. Molina PE, Gardner JD, Souza-Smith FM, and Whitaker AM. Alcohol Abuse: Critical Pathophysiological Processes and Contribution to Disease Burden. Physiology. 2014; 29(3): 203-215.

12. Barnes M, Roychowdhury S, and Nagy LE. Innate Immunity and Cell Death in Alcoholic Liver Disease: Role of Cytochrome P4502E1. Redox Biology. 2014; 2: 929-935.

13. Devaraj S, Ismail S, Ramanathan S, and Yam MF. Investigation of Antioxidant and Hepatoprotective Activity of Standardized Curcuma xanthorrhiza Rhizome in Carbon Tetrachloride-Induced Hepatic Damaged Rats. The Scientific World Journal. 2014; 2014: 1-8.

14. Kumar A. A Review on Hepatoprotective Herbal Drugs. International Journal of Research in Pharmacy and Chemistry. 2012; 2(1): 92-102.

15. Jantan I, Saputri FC, Qaisar MN, and Buang F. Correlation between Chemical Composition of Curcuma domestica and Curcuma xanthorrhiza and their Antioxidant Effect on Human Low- Density Lipoprotein Oxidation. Evidence Based Complement Alternative Medicine. 2012; 2012: 1-10.

16. Pramono S, Arifah FH, Pribadi FH, and Nugroho AE. Hepatoprotective Activity of Curcuma Xanthorrhiza Roxb. on Paracetamol Induced Liver Damage in Rats and Correlation with Their Chemical Compounds. Thai Journal of Pharmaceutical Sciences. 2018; 42(4): 188-195. 